\title{
Meiothermus taiwanensis sp. nov., a novel filamentous, thermophilic species isolated in Taiwan
}

\author{
${ }^{1}$ Department of Botany, \\ National Taiwan \\ University, No. 1, Sec. 4, \\ Roosevelt Rd, 106 Taipei, \\ Taiwan, ROC \\ 2 Department of \\ Microbiology, Tzu Chi \\ University, 970 Hualien, \\ Taiwan, ROC
}

\author{
Mao-Yen Chen, ${ }^{1}$ Guang-Huey Lin, ${ }^{2}$ Yung-Ting Lin ${ }^{1}$ and San-San Tsay ${ }^{1}$ \\ Author for correspondence: San-San Tsay. Tel: +88622363 0231 ext. 2134. Fax: +88622371 8940. \\ e-mail: sstsay@ccms.ntu.edu.tw
}

\begin{abstract}
Two novel filamentous bacterial isolates, strains WR-30' and WR-220, with an optimum growth temperature of approximately $55-60{ }^{\circ} \mathrm{C}$ were isolated from Wu-rai hot springs in the northern part of Taiwan. These isolates were aerobic, thermophilic, non-sporulating, red-pigmented and heterotrophic and formed extremely long, filamentous trichomes from cells of different lengths. Phylogenetic analysis of 16S rDNA, DNA-DNA hybridization, morphological and biochemical features and fatty acid composition revealed that the isolates represent a novel species of the genus Meiothermus. The name Meiothermus taiwanensis sp. nov. is proposed for this novel species. The type strain of $M$.

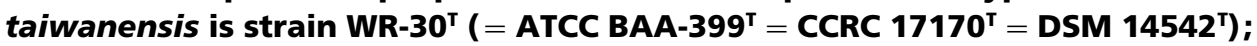
strain WR-220 (= ATCC BAA-400 = CCRC $17171=$ DSM 14543) is a reference strain.
\end{abstract}

Keywords: filamentous bacterium, Meiothermus, hot springs, Taiwan

\section{INTRODUCTION}

Organisms associated with hot springs in geothermal areas have received considerable interest in recent years. Of these thermophilic micro-organisms, members of the genus Thermus, including its type species Thermus aquaticus (Brock \& Freeze, 1969), are aerobic, non-sporulating, heterotrophic rods. However, species of the genus Meiothermus, formerly included in the genus Thermus, can be distinguished from those of the genus Thermus by their lower growth temperature range, the presence of moderate levels of 2-OH fatty acids and $14 \% 16 \mathrm{~S}$ rDNA sequence divergence (Nobre et al., 1996). Meiothermus species form red- or yellowpigmented colonies and have an optimum growth temperature in the range $50-65^{\circ} \mathrm{C}$. They are widely dispersed in hot, natural or aqueous, artificial environments such as domestic and industrial hot-water systems and thermally polluted streams. Four species of bacteria belonging to the genus Meiothermus have been described recently, Meiothermus ruber, Meiothermus chliarophilus, Meiothermus silvanus and Meio-

Published online ahead of print on 18 February 2002 as DOI 10.1099/ ijs.0.02189-0.

The GenBank accession numbers for the $16 \mathrm{~S}$ rDNA sequences of strains WR$30^{\top}$ and WR-220 are AF418001 and AF418002. thermus cerbereus (Loginova et al., 1984; Tenreiro et al., 1995; Nobre et al., 1996; Chung et al., 1997).

This study presents two strains of a novel species of the genus Meiothermus, isolated from Wu-rai hot springs in the northern part of Taiwan. The novel species can be distinguished clearly from other species on the basis of its filamentous morphology and fatty acid composition. However, DNA-DNA hybridization values and phylogenetic analyses of the $16 \mathrm{~S}$ rDNA sequences showed that these isolates have not been described previously. On the basis of the results presented in this study, the name Meiothermus taiwanensis sp. nov. is proposed for this novel species.

\section{METHODS}

Isolation and bacterial strains. Samples of hot spring water, solfataric soil and mud were collected from hot springs located in the Wu-rai area $\left(121^{\circ} 32^{\prime} 4^{\prime \prime} \mathrm{E}, 24^{\circ} 51^{\prime} 52^{\prime \prime} \mathrm{N}\right)$, Taipei, Taiwan. Water samples were transported without temperature control and analysed within $24 \mathrm{~h}$. Untreated, $100 \mu \mathrm{l}$ samples of water were spread directly onto Thermus agar plates (Williams \& da Costa, 1992), which were then sealed in plastic bags and incubated at $50{ }^{\circ} \mathrm{C}$ for 7 days. Colonies were purified by serial transfers. All isolates were preserved in Thermus medium containing $15 \%$ glycerol at $-70{ }^{\circ} \mathrm{C}$. Two isolates, designated WR-30 ${ }^{\mathrm{T}}$ and WR-220, were chosen for in-depth characterization and five strains of 
the genus Meiothermus were used for comparison. The type strains of $M$. ruber (DSM 1279 ${ }^{\mathrm{T}}$ ), $M$. cerbereus (DSM $11376^{\mathrm{T}}$ ), M. chliarophilus (DSM 9957 ) and $M$. silvanus (DSM 9946 ${ }^{\mathrm{T}}$ ) were obtained from the DSMZ. M. ruber NCIMB 11269 was obtained from the National Collection of Industrial, Food and Marine Bacteria, Aberdeen, UK.

Morphological and ultrastructural characteristics. Both light microscopy and TEM were used to observe the morphology of cells. For light microscopy, a Zeiss Axioscop microscope equipped with a Nikon Coolpix 990 digital camera was used routinely to obtain photomicrographs.

For TEM, bacterial strains were grown for $48 \mathrm{~h}$ and washed by centrifugation. For negative staining, $5 \mu$ liquid culture was dropped on Formvar/carbon-coated grids (300 mesh)

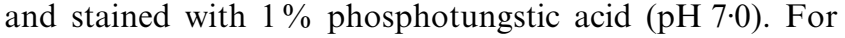
ultrathin sections, cells were fixed in $2.5 \%(\mathrm{w} / \mathrm{v})$ glutaraldehyde for $4 \mathrm{~h}$, followed by $1 \%(\mathrm{w} / \mathrm{v})$ osmium tetroxide in Veronal acetate buffer for $4 \mathrm{~h}$ and $2 \%$ uranyl acetate buffer for $1 \mathrm{~h}$ (Silva, 1973). Samples were dehydrated by a graded acetone series and specimens were embedded in Spurr resin (Spurr, 1969). Sections were cut with an ultramicrotome using a glass knife and stained for $5 \mathrm{~min}$ in post-staining solution (Kostman \& Franceschi, 2000). Electron micrographs were generated using a Hitachi model H7100 electron microscope.

Phenotypic characteristics. All biochemical and tolerance tests were performed as specified previously (Santos et al., 1989; Manaia \& da Costa, 1991) in Thermus medium or on Thermus agar and incubated at $50{ }^{\circ} \mathrm{C}$ for 3 days. The $\mathrm{pH}$ range for growth was determined by measuring the turbidity $(660 \mathrm{~nm})$ of liquid cultures grown at $55^{\circ} \mathrm{C}$. Media with different $\mathrm{pH}$ values were prepared using the appropriate biological buffers (Chung et al., 1997).

Filter-sterilized carbon sources $\left(2 \cdot 0 \mathrm{~g} \mathrm{l}^{-1}\right)$, ammonium sulfate $\left(0.5 \mathrm{~g} \mathrm{l}^{-1}\right)$ and yeast extract $\left(0 \cdot 2 \mathrm{~g} \mathrm{l}^{-1}\right)$ were added to Thermus basal salts for single-carbon-source assimilation tests. Growth was determined by measuring the turbidity $(660 \mathrm{~nm})$ of liquid cultures in $125 \mathrm{ml}$ flasks for 4 days. Positive and negative control cultures were respectively grown in Thermus medium and minimal medium without a carbon source. All growth experiments were conducted in triplicate.

Lipoquinones and polar lipid composition. The cultures used for analysis were grown on Thermus agar at $55^{\circ} \mathrm{C}$ for $48 \mathrm{~h}$. Cells were collected from Petri dishes and lipids were extracted as described previously (Tindall, 1991). Polar lipids were analysed by one-dimensional TLC on silica gel 60 F254 plates $(0 \cdot 25 \mathrm{~mm}$ thickness; Merck) with a solvent system of chloroform/methanol/acetic acid/water $(80: 12$ : $15: 4$ by vol.). TLC plates with separated polar lipid components were observed after staining with molybdophosphoric acid $[10 \%(\mathrm{w} / \mathrm{v})$ in ethanol] and heating at $121^{\circ} \mathrm{C}$ for $30 \mathrm{~min}$.

Lipoquinones were extracted from freeze-dried cells, purified by TLC (Tindall, 1989) and separated using a Hitachi model-L6200 HPLC, equipped with a C-18 reverse-phase column $(250 \times 4.6 \mathrm{~mm}$; particle size $5 \mu \mathrm{m}$; Supelco $)$, with methanol/heptane $(10: 2, \mathrm{v} / \mathrm{v})$ as the mobile phase and detection at $269 \mathrm{~nm}$.

Fatty acid composition. Cultures for fatty acid analysis were grown on Thermus medium plates in sealed plastic bags submerged in a water bath at $50{ }^{\circ} \mathrm{C}$ for $48 \mathrm{~h}$. Fatty acid methyl esters were obtained from fresh wet biomass by saponification, methylation and extraction as described previously (Kuykendall et al., 1988). The fatty acid methyl esters were separated using a Hewlett Packard model 5890 GC equipped with a flame-ionization detector fitted with a $5 \%$ phenylmethyl silicone capillary column $(0 \cdot 2 \mathrm{~mm} \times 25 \mathrm{~m}$; Hewlett Packard). The carrier gas was high-purity $\mathrm{H}_{2}$, the column head pressure was $60 \mathrm{kPa}$, the septum purge was $5 \mathrm{ml} \mathrm{min}{ }^{-1}$, the column split ratio was 55:1 and the injection port temperature was $300^{\circ} \mathrm{C}$. The temperature program of the oven was 170 to $270{ }^{\circ} \mathrm{C}$ at a rate of $5^{\circ} \mathrm{C} \mathrm{min}{ }^{-1}$. Identification and quantification of the fatty acid methyl esters, as well as numerical analysis of the fatty acid profiles, were performed using the standard MIS Library Generation software (Microbial ID).

Determination of mean DNA base composition and DNADNA hybridization. DNA was isolated using a Qiagen DNAeasy tissue kit (Qiagen). The DNA G + C content was determined by HPLC, as described by Mesbah et al. (1989), and phage $\lambda$ DNA was used as a control. DNA-DNA hybridization was elucidated by dot-blot hybridization and radioisotope detection. Probes were prepared using the random-prime labelling system (rediprime II; Amersham Pharmacia) with $\left[\alpha-{ }^{32} \mathrm{P}\right] \mathrm{dCTP}$. All hybridization procedures, including the optimal hybridization temperature and the buffer, followed the specification of Johnson (1984) and Kristjansson et al. (1994). The signals were generated by autoradiography with X-ray film (Kodak X-OMAT) and exposed for the time required to avoid film saturation. The signal produced by self-hybridization of the probe with homologous target DNA was taken as $100 \%$ and the hybridization percentages were calculated for the duplicated dots. Densitometric analyses of signals were processed using the program GEL-PRO version 3.0.

16S rDNA-based phylogenetic analysis. Extraction of genomic DNA, PCR-mediated amplification of the $16 \mathrm{~S}$ rDNA and sequencing of the purified PCR products were performed according to Rainey et al. (1996). PCR-amplified products were purified and sequences were analysed by electrophoresis using a model 373A automatic sequencer (Applied Biosystems). The 16S rDNA sequences were compared with previously determined Meiothermus and Thermus sequences available from the EMBL database using BIOEDIT version 5.0.6 software (Maidak et al., 1994). Evolutionary distances were calculated according to Jukes \& Cantor (1969). The phylogenetic dendrogram was generated from evolutionary distances by the neighbour-joining method (Saitou \& Nei, 1987) using BIOEDIT software.

\section{RESULTS}

\section{Isolation of strains}

Five samples, including hot spring water, solfataric soil and mud, were taken from Wu-rai hot springs, Taipei, Taiwan. The temperature range in situ was $50-80{ }^{\circ} \mathrm{C}$ and the $\mathrm{pH}$ values of the samples, determined at the ambient temperature, were between $6 \cdot 2$ and $7 \cdot 9$. Following incubation at $50{ }^{\circ} \mathrm{C}$ for $72 \mathrm{~h}$, red- and yellow-pigmented colonies were observed on the surface of a Thermus agar plate. After serial transfer and purification, the yellow-pigmented colonies that grew at higher temperatures (over $70^{\circ} \mathrm{C}$ ) were considered to be members of the genus Thermus and red-pigmented 


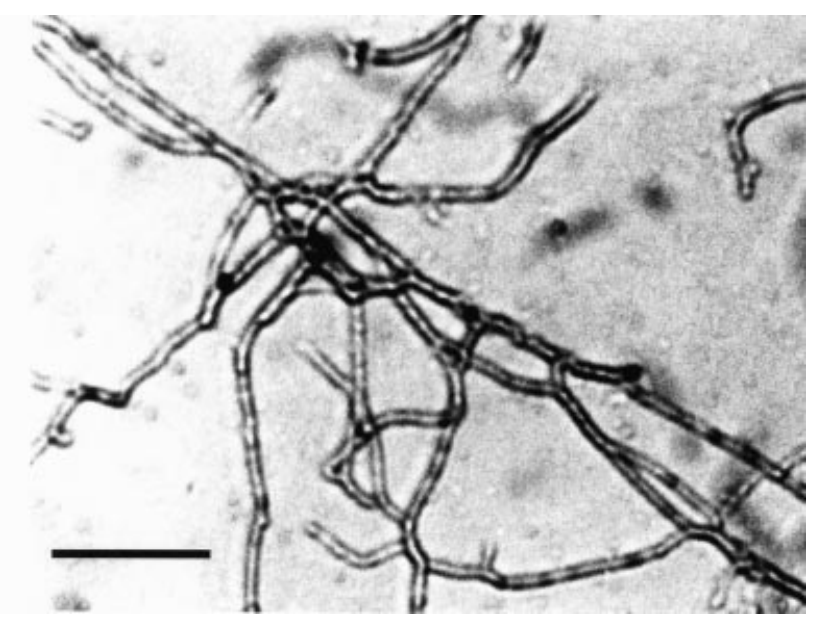

Fig. 1. Phase-contrast micrograph showing the filamentous morphology of strain WR-30'. Bar, $10 \mu \mathrm{m}$.

colonies grown at lower temperature (about $50{ }^{\circ} \mathrm{C}$ ) were considered to be members of the genus Meiothermus. Two isolates, WR $-30^{\mathrm{T}}$ and WR-220, which had different morphological properties, were selected for this study.

\section{Morphological and ultrastructural characteristics}

Cells of the isolates stained Gram-negative and formed long filaments; motility and spores were not observed. Septa were not visible by phase-contrast microscopy (Fig. 1). Colonies on Thermus medium were red- and red/orange-pigmented and formed a thin film on the surface of agar plates. TEM with negative staining showed that the morphology of strain WR-30 $0^{T}$ was filamentous (Fig. 2a). Thin sections showed that the cell wall had a complex multilayered appearance. A thin electron-dense layer surrounded by a thick corrugated layer was adjacent to the cell membrane. The corrugated layer outside the cell wall ran continuously along the filaments and no septum formation was evident (Fig. 2b). Except for that of the outermost layer, the cell wall structure closely resembled that of the genus Meiothermus (Tenreiro et al., 1995).

\section{Phenotypic and biochemical characteristics}

The temperature range for growth of strain WR-30 was $40-70{ }^{\circ} \mathrm{C}$ and the optimum growth temperature was $55^{\circ} \mathrm{C}$ on Thermus medium. The optimum $\mathrm{pH}$ was approximately 8.0 at the optimum growth temperature.

Several biochemical characteristics, such as the presence of cytochrome oxidase and catalase, the utilization of a single carbon source and the hydrolysis of carbohydrate polymers, were identical in strains WR $30^{\mathrm{T}}$ and WR-220 and other type strains of the genus Meiothermus. The main differences in biochemi-
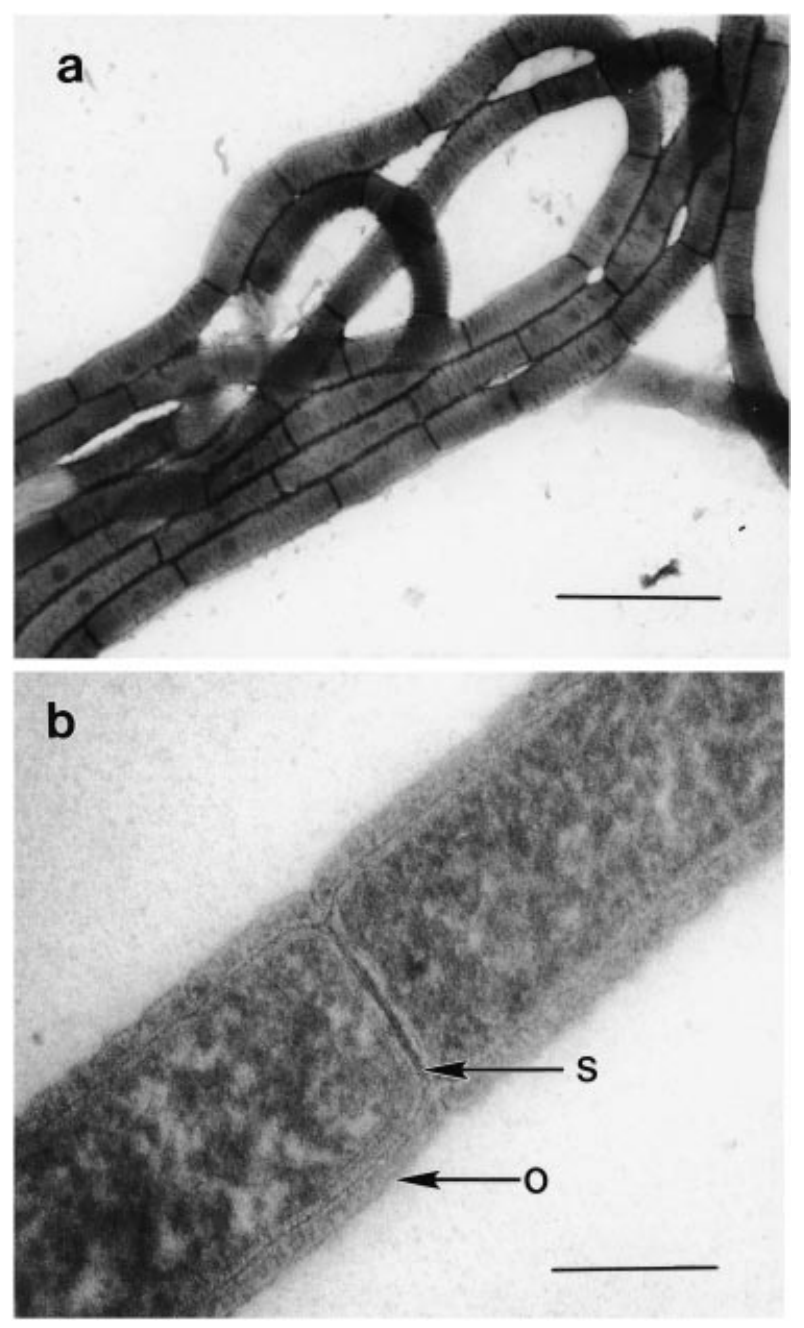

Fig. 2. TEM of strain WR-30'. (a) Negatively stained multiple filaments of strain WR- $30^{\top}$ (bar, $\left.2 \mu \mathrm{m}\right)$; (b) thin-section electron micrograph of strain WR- $30^{\top}$ showing the septum $(\mathrm{S})$ and the outer cell wall layer (O) running continuously along the filament (bar, $0.2 \mu \mathrm{m})$.

cal characteristics were observed during assimilation of single carbon sources. Three carbon sources, Larabinose, ribitol and D-trehalose, could be utilized by strains WR-30 $0^{\mathrm{T}}$ and WR-220; these carbon sources cannot be utilized by other strains of the genus Meiothermus. The two isolated strains could also be distinguished from each other by the utilization of $\mathrm{D}$ mannitol, D-raffinose and succinate. Table 1 presents the biochemical characteristics of strains WR- $30^{\mathrm{T}}$ and WR-220 and other Meiothermus species.

\section{Lipoquinones and polar lipid composition}

The polar lipids of the tested strains included one major phospholipid and two prominent glycolipids, designated GL-1a and GL-1b. GL-1a and GL-1b migrated close to each other near the origin of the TLC assay. Strains WR-30 $0^{\mathrm{T}}$ and WR-220 generally con- 
Table 1. Biochemical features that distinguish species of the genus Meiothermus

Strains/species: 1, WR-30"T ; WR-220; 3, M. ruber; 4, M. cerbereus; 5, M. chliarophilus; 6, M. silvanus. All strains were grown at $55^{\circ} \mathrm{C}$ except $M$. chliarophilus, which was grown at $50{ }^{\circ} \mathrm{C} .+$, Positive result or growth; - , negative result or no growth; w, weak result. All strains hydrolysed elastin, fibrin, gelatin, casein and DNA and were positive for $\beta$-galactosidase and oxidase. D-Fructose, D-galactose, D-glucose, D-mannose, D-melibiose, lactose, L-glutamate, maltose and sucrose were utilized by all of the strains. None of the strains hydrolysed xylan or utilized citrate.

\begin{tabular}{|c|c|c|c|c|c|c|}
\hline Characteristic & 1 & 2 & 3 & 4 & 5 & 6 \\
\hline Pigmentation & Red & Red & Red & Red & Yellow & Red \\
\hline \multicolumn{7}{|l|}{ Presence of: } \\
\hline Catalase & + & + & + & - & - & - \\
\hline$\alpha$-Galactosidase & + & + & + & + & + & - \\
\hline \multicolumn{7}{|l|}{ Hydrolysis of: } \\
\hline Starch & - & - & - & - & + & - \\
\hline Aesculin & + & + & + & + & + & - \\
\hline \multicolumn{7}{|l|}{ Utilization of: } \\
\hline D-Cellobiose & + & + & + & + & + & - \\
\hline D-Mannitol & + & - & + & - & + & - \\
\hline D-Raffinose & + & - & + & - & + & - \\
\hline D-Sorbitol & $+\mathrm{w}$ & + & + & - & + & - \\
\hline D-Trehalose & - & + & + & + & + & - \\
\hline D-Xylose & + & + & + & - & + & + \\
\hline Glycerol & - & - & + & - & + & - \\
\hline L-Arabinose & + & + & - & - & - & - \\
\hline L-Rhamnose & $+\mathrm{w}$ & - & - & - & - & - \\
\hline Malate & - & - & + & - & - & - \\
\hline myo-Inositol & + & + & + & - & + & - \\
\hline Pyruvate & + & + & - & + & + & + \\
\hline Ribitol & + & + & - & - & - & - \\
\hline Succinate & + & - & + & - & - & - \\
\hline L-Asparagine & $+\mathrm{w}$ & + & + & - & + & + \\
\hline L-Glutamine & + & + & + & - & + & + \\
\hline L-Serine & - & - & + & - & + & + \\
\hline L-Arginine & + & + & + & - & + & + \\
\hline
\end{tabular}

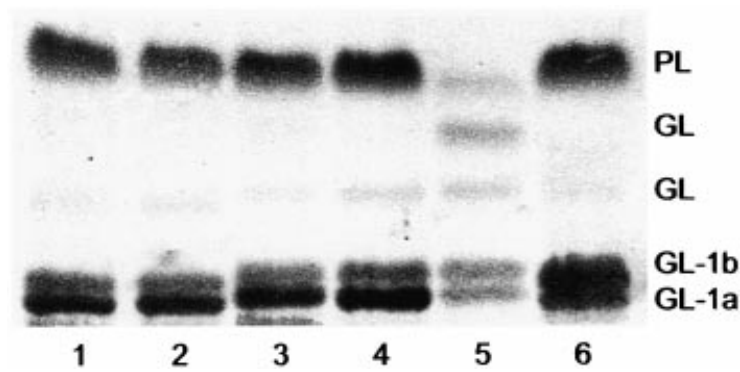

Fig. 3. One-dimensional TLC of polar lipids of Meiothermus strains. Components were revealed by staining the TLC plates with molybdophosphoric acid and heating at $121^{\circ} \mathrm{C}$ for $30 \mathrm{~min}$. Lanes: 1 , WR-30 $; 2$, WR-220; 3, M. ruber DSM 1279 ; 4, M. silvanus DSM 9946'; 5, M. chliarophilus DSM 9957'; 6, M. cerbereus DSM $11376^{\top}$. PL, Phospholipid; GL-1a, glycolipid-1a; GL-1b, glycolipid-1b; GL, minor glycolipid.

tained minor glycolipids. Fig. 3 depicts the polar lipids of tested strains of the genus Meiothermus assayed by one-dimensional TLC. The respiratory lipoquinone of strain WR- $30^{\mathrm{T}}$, like that of other members of the genus Meiothermus, was menaquinone-8 (MK-8).

\section{Fatty acid composition}

Table 2 presents the composition of fatty acids of all tested organisms obtained following extraction, methylation and saponification of lipids and GC. The fatty acid composition of strains WR-30 ${ }^{\mathrm{T}}$ and WR-220 corroborates the assignment of these isolates to the genus Meiothermus, since both strains possessed 2-OH iso and anteiso fatty acids. The fatty acid composition of these strains was, however, very similar to those of the type strains of all the described species of the genus Meiothermus. The major fatty acids of strains WR $-30^{\mathrm{T}}$ and WR-220 were 15:0 iso and 17:0 iso; 15:0 iso fatty acids were present at higher levels than 15:0 anteiso fatty acids. The major distinguishing characteristic was relatively large amounts of 18:0 iso diol. The only other species that has this diol, in small amounts, is the type strain of $M$. silvanus, where it reached about $2 \%$ of the total fatty acids. Strains WR- $30^{\mathrm{T}}$ and WR-220 
Table 2. Fatty acid composition of type strains of Meiothermus species and strains WR$30^{\top}$ and WR-220 grown at $50^{\circ} \mathrm{C}$

Strain/species: 1 , WR-30" $; 2$, WR-220; 3, M. ruber ; 4, M. silvanus; 5, M. chliarophilus; 6, M. cerbereus. Values are percentages of total fatty acids. -, Not detectable; ECL, equivalent chain length.

\begin{tabular}{|c|c|c|c|c|c|c|c|}
\hline Fatty acid & ECL & 1 & 2 & 3 & 4 & 5 & 6 \\
\hline $13: 0$ iso & $12 \cdot 612$ & $0 \cdot 7$ & $0 \cdot 7$ & $0 \cdot 4$ & $0 \cdot 4$ & $1 \cdot 6$ & $1 \cdot 5$ \\
\hline $14: 0$ iso & $13 \cdot 618$ & $0 \cdot 7$ & $0 \cdot 7$ & $1 \cdot 3$ & $0 \cdot 6$ & $1 \cdot 9$ & $2 \cdot 6$ \\
\hline $13: 0$ iso $3-\mathrm{OH}$ & $14 \cdot 110$ & $1 \cdot 1$ & $1 \cdot 1$ & $0 \cdot 4$ & $1 \cdot 0$ & - & - \\
\hline $15: 1$ iso $F^{*}$ & $14 \cdot 414$ & $0 \cdot 3$ & $0 \cdot 5$ & $1 \cdot 3$ & - & - & $4 \cdot 1$ \\
\hline $15: 0$ iso & $14 \cdot 621$ & $38 \cdot 4$ & $31 \cdot 8$ & $30 \cdot 9$ & $25 \cdot 9$ & $39 \cdot 0$ & $35 \cdot 5$ \\
\hline $15: 0$ anteiso & $14 \cdot 711$ & $2 \cdot 9$ & $6 \cdot 5$ & $6 \cdot 5$ & $22 \cdot 5$ & $8 \cdot 9$ & $6 \cdot 2$ \\
\hline $15: 0$ & $15 \cdot 000$ & $2 \cdot 0$ & $1 \cdot 6$ & $3 \cdot 3$ & $0 \cdot 2$ & $1 \cdot 8$ & $2 \cdot 0$ \\
\hline $16: 1 \omega 7 t$ alcohol & $15 \cdot 415$ & - & - & $0 \cdot 7$ & - & - & $2 \cdot 0$ \\
\hline $16: 0$ iso & $15 \cdot 626$ & $2 \cdot 6$ & $2 \cdot 7$ & $4 \cdot 8$ & $1 \cdot 6$ & $2 \cdot 2$ & $4 \cdot 1$ \\
\hline $15: 0$ iso $2-\mathrm{OH}$ & $15 \cdot 847$ & $0 \cdot 7$ & $1 \cdot 1$ & $0 \cdot 5$ & $0 \cdot 4$ & $0 \cdot 5$ & $0 \cdot 4$ \\
\hline $16: 0$ & $16 \cdot 000$ & $6 \cdot 1$ & $6 \cdot 5$ & $4 \cdot 9$ & $5 \cdot 5$ & $8 \cdot 2$ & $5 \cdot 1$ \\
\hline Unknown & $16 \cdot 090$ & $0 \cdot 4$ & $0 \cdot 9$ & $0 \cdot 5$ & $1 \cdot 6$ & $0 \cdot 7$ & $0 \cdot 6$ \\
\hline $15: 0$ iso $3-\mathrm{OH}$ & $16 \cdot 135$ & - & - & $0 \cdot 2$ & - & $1 \cdot 1$ & $0 \cdot 6$ \\
\hline $15: 02-\mathrm{OH}$ & $16 \cdot 217$ & $0 \cdot 3$ & - & $0 \cdot 9$ & - & $0 \cdot 4$ & $0 \cdot 4$ \\
\hline $17: 1$ iso $\omega 9 c$ & $16 \cdot 411$ & $1 \cdot 1$ & 1.9 & $3 \cdot 4$ & - & - & $5 \cdot 2$ \\
\hline $17: 0$ iso & $16 \cdot 629$ & $17 \cdot 4$ & $16 \cdot 3$ & $16 \cdot 5$ & $12 \cdot 7$ & $13 \cdot 4$ & $6 \cdot 0$ \\
\hline $17: 0$ anteiso & $16 \cdot 722$ & $2 \cdot 4$ & $6 \cdot 3$ & $4 \cdot 4$ & $6 \cdot 9$ & $2 \cdot 5$ & $1 \cdot 6$ \\
\hline $17: 1 \omega 8 c$ & $16 \cdot 792$ & - & - & $0 \cdot 6$ & - & - & $0 \cdot 7$ \\
\hline $17: 1 \omega 6 c$ & $16 \cdot 862$ & $0 \cdot 3$ & $0 \cdot 4$ & $0 \cdot 9$ & $1 \cdot 0$ & $0 \cdot 9$ & $1 \cdot 0$ \\
\hline $17: 0$ & $17 \cdot 000$ & $1 \cdot 7$ & $1 \cdot 5$ & $2 \cdot 1$ & $0 \cdot 3$ & $1 \cdot 1$ & $0 \cdot 4$ \\
\hline $16: 02-\mathrm{OH}$ & $17 \cdot 235$ & $1 \cdot 0$ & $1 \cdot 2$ & $0 \cdot 6$ & $0 \cdot 4$ & $0 \cdot 7$ & $0 \cdot 7$ \\
\hline $17: 0$ iso $2-\mathrm{OH}$ & $17 \cdot 872$ & $12 \cdot 0$ & $10 \cdot 4$ & $6 \cdot 8$ & $9 \cdot 6$ & $10 \cdot 9$ & $5 \cdot 7$ \\
\hline $17: 0$ anteiso $2-\mathrm{OH}$ & $17 \cdot 968$ & $0 \cdot 2$ & $0 \cdot 7$ & $0 \cdot 3$ & $3 \cdot 0$ & $0 \cdot 8$ & - \\
\hline $17: 0$ iso $3-\mathrm{OH}$ & $18 \cdot 164$ & - & $0 \cdot 6$ & $1 \cdot 5$ & - & $0 \cdot 2$ & $4 \cdot 7$ \\
\hline 17:0 2-OH & $18 \cdot 249$ & $0 \cdot 7$ & $0 \cdot 7$ & - & - & $0 \cdot 3$ & $0 \cdot 8$ \\
\hline $17: 0$ anteiso $3-\mathrm{OH}$ & $18 \cdot 260$ & - & - & $1 \cdot 0$ & - & - & - \\
\hline $19: 0$ iso & $18 \cdot 633$ & $0 \cdot 3$ & - & - & $1 \cdot 8$ & $0 \cdot 2$ & - \\
\hline 19:0 anteiso & $18 \cdot 729$ & - & - & - & $1 \cdot 1$ & - & - \\
\hline $18: 0$ iso diol & $19 \cdot 060$ & $4 \cdot 5$ & $3 \cdot 1$ & $0 \cdot 7$ & $2 \cdot 2$ & - & - \\
\hline 18:0 anteiso diol & $19 \cdot 160$ & - & $0 \cdot 3$ & - & $0 \cdot 4$ & - & - \\
\hline
\end{tabular}

* The double bond position of this fatty acid is not known.

had higher levels of 18:0 iso diol, respectively reaching 4.5 and $3 \cdot 1 \%$ of the total fatty acids.

\section{Mean base composition of DNA and DNA-DNA relatedness}

The $\mathrm{G}+\mathrm{C}$ content of the DNA of isolate WR $-30^{\mathrm{T}}$ was $61.4 \mathrm{~mol} \%$ and that of WR-220 was $61.9 \mathrm{~mol} \%$, according to the HPLC method. To elucidate interrelatedness from DNA-DNA hybridization, all type strains of species of the genus Meiothermus and strains WR-30 ${ }^{\mathrm{T}}$ and WR-220 were used. Strain WR-30 ${ }^{\mathrm{T}}$ showed $57.4 \%$ relatedness to $M$. ruber DSM $1279^{\mathrm{T}}$, $50.8 \%$ relatedness to $M$. cerbereus DSM $11376^{\mathrm{T}}$, $19.5 \%$ relatedness to $M$. silvanus DSM $9446^{\mathrm{T}}, 28.7 \%$ relatedness to $M$. chliarophilus DSM $9957^{\mathrm{T}}$ and $51 \cdot 2 \%$ relatedness to $M$. ruber NCIMB 11269. Table 3 presents the DNA relatedness among strains WR $-30^{\mathrm{T}}$,
WR-220 and the other type strains of Meiothermus species.

\section{S rDNA-based phylogenetic analysis}

Following PCR amplification and sequencing, 16S rDNA sequences of $1483 \mathrm{nt}$ (strain $\mathrm{WR}-30^{\mathrm{T}}$ ) and $1482 \mathrm{nt}$ (strain WR-220) were determined. A comparison of the $16 \mathrm{~S}$ rDNA sequences of strains WR-30 ${ }^{\mathrm{T}}$ and WR-220 with reference sequence data in the EMBL database revealed that these strains belonged to the genus Meiothermus. A more detailed analysis based on a dataset consisting of at least 1400 unambiguous nucleotides between positions 28 and 1526 (Escherichia coli numbering; Brosius et al., 1978) revealed that these isolates were most closely related to the Thermus / Meiothermus group. Strains WR $-30^{\mathrm{T}}$ and WR-220, which have identical 16S rDNA sequences 
Table 3. DNA-DNA hybridization among strains $W R-30^{\top}, W R-220$ and type strains of Meiothermus species

\begin{tabular}{|lccccccc|}
\hline Strain & $\mathbf{1}$ & $\mathbf{2}$ & $\mathbf{3}$ & $\mathbf{4}$ & $\mathbf{5}$ & $\mathbf{6}$ & $\mathbf{7}$ \\
\hline 1. M. taiwanensis WR-30 & 100 & & & & & & \\
2. M. taiwanensis WR-220 & $94 \cdot 3$ & 100 & & & & & \\
3. M. ruber DSM 1279 & $54 \cdot 3$ & $47 \cdot 6$ & 100 & & & & \\
4. . silvanus DSM 9446 & $19 \cdot 5$ & $23 \cdot 8$ & $17 \cdot 9$ & 100 & & & \\
5. M. chliarophilus DSM $9957^{\mathrm{T}}$ & $28 \cdot 7$ & $28 \cdot 7$ & $20 \cdot 5$ & $39 \cdot 2$ & 100 & & \\
6. . cerbereus DSM $11376^{\mathrm{T}}$ & $50 \cdot 8$ & $47 \cdot 1$ & $49 \cdot 6$ & $24 \cdot 3$ & $28 \cdot 9$ & 100 & \\
7. M. ruber NCIMB 11269 & $51 \cdot 2$ & $61 \cdot 3$ & $75 \cdot 6$ & $17 \cdot 4$ & $22 \cdot 3$ & $33 \cdot 5$ & 100 \\
\hline
\end{tabular}

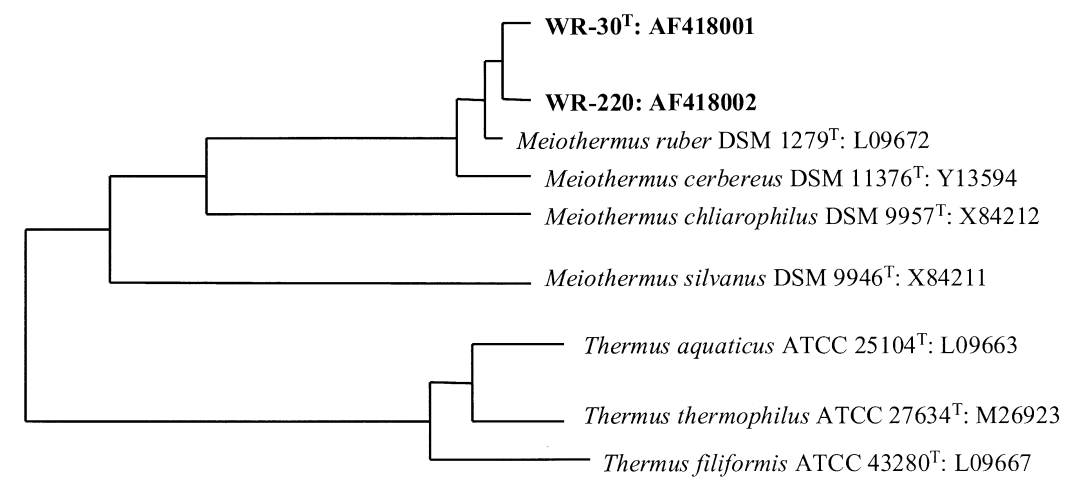

Fig. 4. $16 \mathrm{~S}$ rDNA phylogenetic dendrogram showing relationships among various species of the genera Thermus and Meiothermus. Bar, $5 \%$ evolutionary distance.

over all positions, exhibited the highest mutual similarity $(99 \cdot 46 \%)$ and formed a sister cluster next to the type strain of $M$. ruber. The similarities between the $16 \mathrm{~S}$ rDNA sequence of the WR-30 $/$ WR-220 cluster and those of $M$. ruber and $M$. cerbereus were respectively 98.4 and $97.0 \%$. The similarities between the $16 \mathrm{~S}$ rDNA sequence of strains WR $-30^{\mathrm{T}}$ and WR220 and those of other Meiothermus species were lower: $88.3 \%$ for $M$. silvanus and $91.5 \%$ for $M$. chliarophilus. Fig. 4 shows a 16S rDNA-based phylogenetic dendrogram generated by the neighbourjoining method.

\section{DISCUSSION}

Areas with geothermal springs are widely situated on the Earth's surface, but 'hot spots', where thermal environments are abundant, are restricted to areas associated with past or present volcanic activity such as the USA (Yellowstone National Park), the former USSR, Iceland, Italy, New Zealand and Japan. Many thermophilic micro-organisms have been isolated and studied from such places. Taiwan is in the circumPacific volcanic zone and exhibits many geothermal environments. Results obtained from preliminary studies (Chen et al., 2000) have provided the basis for future investigation in the field of thermophilic microorganisms in geothermal environments in Taiwan.

Bacteria of the genus Meiothermus are Gram-negative, heterotrophic, non-motile, pleomorphic rod-shaped cells with short filaments; they live aerobically at neutral $\mathrm{pH}$ and grow well at temperatures above $50{ }^{\circ} \mathrm{C}$. These thermophiles are widely distributed in various areas such as geothermal hot springs and artificial thermal environments. 16S rDNA sequence analysis showed that strains WR-30 $0^{\mathrm{T}}$ and WR-220 are members of the genus Meiothermus and related to $M$. ruber. Strains WR-30 $0^{\mathrm{T}}$ and WR-220 had high $16 \mathrm{~S}$ rDNA sequence similarity to the type strain of $M$. ruber, but the WR-30 $/$ WR-220 cluster was separate from $M$. ruber. Low DNA-DNA hybridization values showed that strains WR-30 $30^{\mathrm{T}}$ and WR-220 represent an independent species of the genus Meiothermus. Similar results were also observed in studies of $M$. ruber and M. cerbereus (Chung et al., 1997).

The presence of 2-OH fatty acids in relatively moderate proportions, ranging between 8 and $14 \%$, is a chemotaxonomic characteristic of all species of the genus Meiothermus (Nobre et al., 1996). Significant levels of 2-OH fatty acids were also present in strains of the novel species. The presence of higher levels of 18:0 iso 
diol fatty acids appears to be a useful distinguishing characteristic. The only other species in the genus Meiothermus that has this diol, in small amounts, is the type strain of $M$. silvanus. Strains WR-30 $0^{\mathrm{T}}$ and WR220 had higher levels of 18:0 iso diol fatty acids than did M. silvanus.

The morphology of the micro-organisms is constant and clear enough to distinguish these isolates from other species. Previous studies have revealed filamentous, thermophilic micro-organisms in different habitats. These include the photosynthetic bacterium Chloroflexus aurantiacus (Pierson \& Castenholz, 1974), the phototrophic bacterium Heliothrix oregonensis (Pierson et al., 1985) and the heterotrophic bacteria Geobacillus thermocatenulatus, Anoxybacillus flavithermus (Golovacheva et al., 1975; Heinen et al., 1982; Pikuta et al., 2000) and Thermus filiformis (Hudson et al., 1987). In culture, most strains of the genera Thermus and Meiothermus form pleomorphic rodshaped cells and short filaments (Brock, 1978). Species of Thermus and Meiothermus can become filamentous under certain culture conditions, such as addition of some D-amino acids to the growth medium (Brock \& Freeze, 1969; Loginova et al., 1984). Most Thermus species produce rod-shaped cells, with the exception of the type strain of $T$. filiformis, which always produces very long intertwined filaments; rod-shaped cells have never been observed (Hudson et al., 1987). It has an extra wall layer, external to the corrugated layer, which runs interruptedly over zones of septum formation. Similar morphological features were observed in strains WR-30 ${ }^{\mathrm{T}}$ and WR-220. These novel Meiothermus isolates are morphologically filamentous, like the type strain of $T$. filiformis, but differences were also noted. Several morphological features such as midfilament swellings of trichomes and small spheres between cells, evident in $T$. filiformis, were not observed in strains WR-30 ${ }^{\mathrm{T}}$ and WR-220.

Differences in morphological characteristics, 16S rDNA sequence divergence, the low DNA-DNA hybridization values with $M$. ruber and the distinctive fatty acid composition, with high proportions of 18:0 iso diol fatty acids, show that isolates $\mathrm{WR}-30^{\mathrm{T}}$ and WR-220 represent a novel species belonging to the genus Meiothermus, for which the name Meiothermus taiwanensis sp. nov. is proposed.

\section{Description of Meiothermus taiwanensis sp. nov.}

Meiothermus taiwanensis (tai.wan.en'sis. N.L. fem. adj. taiwanensis of Taiwan, from the hot springs of Taiwan where the bacterium was first isolated).

Forms stable trichomes of indeterminate length (several hundred micrometres). Variable-length cells make filamentous trichomes and the cell lengths are 1.4 $2.4 \mu \mathrm{m}$. Short filaments are also present. Septa are not visible by phase-contrast microscopy. Gram staining yields negative results. Cells are non-motile and do not form spores. Colonies on Thermus medium are redand red/orange-pigmented, 2-3 $\mathrm{mm}$ in diameter after incubation for $72 \mathrm{~h}$ at $55^{\circ} \mathrm{C}$ and form a thin film on the surface of agar plates. The temperature range for growth of the type strain is $40-70^{\circ} \mathrm{C}$ and the optimum growth temperature is $55^{\circ} \mathrm{C}$. The optimum $\mathrm{pH}$ for growth is approximately 8.0 . The major fatty acids are $15: 0$ iso and 17:0 iso; $2-\mathrm{OH}$ iso and anteiso fatty acids such as 17:0 iso $2-\mathrm{OH}$ are also present. The major distinguishing characteristic is the relatively high level of 18:0 iso diol fatty acid. Positive for $\alpha$-galactosidase, $\beta$-galactosidase, oxidase and catalase, hydrolysis of elastin, fibrin, gelatin, casein and DNA and degradation of aesculin. The type strain can utilize Dcellobiose, D-fructose, D-galactose, D-glucose, D-mannose, D-mannitol, L-rhamnose, D-melibiose, D-sorbitol, D-xylose, lactose, L-arabinose, L-glutamate, maltose, myo-inositol, pyruvate, ribitol, succinate, sucrose, L-asparagine, L-glutamine, L-proline and L-arginine as carbon sources. It does not hydrolyse starch or xylan and does not utilize citrate, D-trehalose, glycerol, malate or L-serine. The DNA G $+\mathrm{C}$ content of the type strain is $61.9 \mathrm{~mol} \%$.

The type strain is strain WR-30 ${ }^{\mathrm{T}}$ (= ATCC BAA-399 $\left.=\mathrm{CCRC} 17170^{\mathrm{T}}=\mathrm{DSM} 14542^{\mathrm{T}}\right)$ and strain WR-220 $(=$ ATCC BAA-400 = CCRC $17171=$ DSM 14543) is a reference strain; both strains were isolated from the Wu-rai hot springs of Taipei in northern Taiwan.

\section{ACKNOWLEDGEMENTS}

The authors would like to thank the National Science Council of the Republic of China for supporting this research financially under grants nos NSC89-2311-B-002020 and MSC90-2317-B002-010 (S.-S. T.) and NSC90-2320B-320-007 (G.-H.L.). We also appreciate Professor Milton da Costa (Universidade de Coimbra, Coimbra, Portugal) for his valuable advice and help on the analysis of fatty acids, Dr R. A. D. Williams (Queen Mary and Westfield College, London, UK) and Professor J. A. Buswell (The Chinese University of Hong Kong, Hong Kong) for their valuable advice on the isolation of hot-spring micro-organisms, Professor Shin-Tung Liu (Chang Gung University) for performing DNA hybridization and preserving micro-organisms and Miss Ching-Yen Lin and Mr Chih-Yuan Tang (Advanced Instrumentation Center, National Taiwan University) for performing electron microscopy.

\section{REFERENCES}

Brock, T. D. (1978). Thermophilic Microorganisms and Life at High Temperatures. New York: Springer.

Brock, T. D. \& Freeze, H. (1969). Thermus aquaticus gen. n., and sp. n., a nonsporulating extreme thermophile. J Bacteriol 98, 289-297.

Brosius, J., Palmer, M. L., Kennedy, P. J. \& Noller, H. F. (1978). Complete nucleotide sequence of a $16 \mathrm{~S}$ ribosomal RNA gene from Escherichia coli. Proc Natl Acad Sci U S A 75, 4801-4805.

Chen, M.-Y., Chen, Z.-C., Chen, K.-Y. \& Tsay, S.-S. (2000). Fungal flora of hot springs of Taiwan (1): Wu-Rai. Taiwania 45, 207-216.

Chung, A. P., Rainey, F., Nobre, M. F., Burghardt, J. \& da Costa, M. S. (1997). Meiothermus cerbereus sp. nov., a new slightly thermophilic species with high levels of 3-hydroxy fatty acids. Int $J$ Syst Bacteriol 47, 1225-1230.

Golovacheva, R. S., Loginova, L. G., Salikhov, T. A., Kolesnikov, A. A. \& Zaitseva, G. N. (1975). A new thermophilic species, Bacillus thermocatenulatus nov. sp. Mikrobiologiya 44, 265-268. 
Heinen, W., Lauwers, A. M. \& Mulders, J. W. M. (1982). Bacillus flavothermus, a newly isolated facultative thermophile. Antonie van Leeuwenhoek 48, 265-272.

Hudson, J. A., Morgan, H. W. \& Daniel, R. M. (1987). Thermus filiformis sp. nov., a filamentous caldoactive bacterium. Int $J$ Syst Bacteriol 37, 431-436.

Johnson, J. L. (1984). Nucleic acids in bacterial classification. In Bergey's Manual of Systematic Bacteriology, vol. 1, pp. 8-11. Edited by N. R. Krieg \& J. G. Holt. Baltimore: Williams \& Wilkins.

Jukes, T. H. \& Cantor, C. R. (1969). Evolution of protein molecules. In Mammalian Protein Metabolism, vol. 3, pp. 21-132. Edited by H. N. Munro. New York: Academic Press.

Kostman, T. A. \& Franceschi, V. R. (2000). Cell and calcium oxalate crystal growth is coordinated to achieve high-capacity calcium regulation in plants. Protoplasma 214, 166-179.

Kristjansson, J. K., Hjorleifsdottir, S., Marteinsson, V. T. \& Alfredsson, G. A. (1994). Thermus scotoductus, sp. nov., a pigment-producing thermophilic bacterium from hot tap water in Iceland and including Thermus sp. X-1. Syst Appl Microbiol 17, 44-50.

Kuykendall, L. D., Roy, M. A., O’Neill, J. J. \& Devine, T. E. (1988). Fatty acids, antibiotic resistance, and deoxyribonucleic acid homology groups of Bradyrhizobium japonicum. Int J Syst Bacteriol 38, 358-361.

Loginova, L. G., Egorova, L. A., Golovacheva, R. S. \& Seregina, L. M. (1984). Thermus ruber sp. nov., nom. rev. Int J Syst Bacteriol 34, 498-499.

Maidak, B. L., Larsen, N., McCaughey, M. J., Overbeek, R., Olsen, G. J., Fogel, K., Blandy, J. \& Woese, C. R. (1994). The Ribosomal Database Project. Nucleic Acids Res 22, 3485-3487.

Manaia, C. M. \& da Costa, M. S. (1991). Characterization of halotolerant Thermus isolates from shallow marine hot springs on $\mathrm{S}$. Miguel, Azores. J Gen Microbiol 137, 2643-2648.

Mesbah, M., Premachandran, U. \& Whitman, W. B. (1989). Precise measurement of the $\mathrm{G}+\mathrm{C}$ content of deoxyribonucleic acid by highperformance liquid chromatography. Int J Syst Bacteriol 39, 159-167.

Nobre, M. F., Trüper, H. G. \& da Costa, M. S. (1996). Transfer of Thermus ruber (Loginova et al. 1984), Thermus silvanus (Tenreiro et al. 1995), and Thermus chliarophilus (Tenreiro et al. 1995) to Meiothermus gen. nov. as Meiothermus ruber comb. nov., Meiothermus silvanus comb. nov., and Meiothermus chliarophilus comb. nov, respectively, and emendation of the genus Thermus. Int J Syst Bacteriol 46, 604-606.
Pierson, B. K. \& Castenholz, R. W. (1974). A phototrophic gliding filamentous bacterium of hot springs, Chloroflexus aurantiacus, gen. and sp. nov. Arch Microbiol 100, 5-24.

Pierson, B. K., Giovannoni, S. J., Stahl, D. A. \& Castenholz, R. W. (1985). Heliothrix oregonensis, gen. nov., sp. nov., a phototrophic filamentous gliding bacterium containing bacteriochlorophyll $a$. Arch Microbiol 142, 164-167.

Pikuta, E., Lysenko, A., Chuvilskaya, N., Mendrock, U., Hippe, H., Suzina, N., Nikitin, D., Osipov, G. \& Laurinavichius, K. (2000). Anoxybacillus pushchinensis gen. nov., sp. nov., a novel anaerobic, alkaliphilic, moderately thermophilic bacterium from manure, and description of Anoxybacillus flavithermus comb. nov. Int J Syst Evol Microbiol 50, 2109-2117.

Rainey, F. A., Ward-Rainey, N., Kroppenstedt, R. M. \& Stackebrandt, E. (1996). The genus Nocardiopsis represents a phylogenetically coherent taxon and a distinct actinomycete lineage: proposal of Nocardiopsaceae fam. nov. Int J Syst Bacteriol 46, 1088-1092.

Saitou, N. \& Nei, M. (1987). The neighbor-joining method: a new method for reconstructing phylogenetic trees. Mol Biol Evol 4, 406-425.

Santos, M. A., Williams, R. A. D. \& da Costa, M. S. (1989). Numerical taxonomy of Thermus isolates from hot springs in Portugal. Syst Appl Microbiol 12, 310-315.

Silva, M. T. \& Sousa, J. C. F. (1973). Ultrastructure of the cell wall and cytoplasmic membrane of Gram-negative bacteria with different fixation techniques. J Bacteriol 113, 953-962.

Spurr, A. R. (1969). A low-viscosity epoxy resin embedding medium for electron microscopy. $J$ Ultrastruct Res 26, 31-43.

Tenreiro, S., Nobre, M. F. \& da Costa, M. S. (1995). Thermus silvanus sp. nov. and Thermus chliarophilus sp. nov., two new species related to Thermus ruber but with lower growth temperatures. Int J Syst Bacteriol 45, 633-639.

Tindall, B. J. (1989). Fully saturated menaquinones in the archaebacterium Pyrobaculum islandicum. FEMS Microbiol Lett 60, 251-254.

Tindall, B. J. (1991). Lipid composition of Rhodothermus marinus. FEMS Microbiol Lett 80, 65-68.

Williams, R. A. D. \& da Costa, M. S. (1992). The genus Thermus and related microorganisms. In The Prokaryotes, 2nd edn, pp. 3745-3753. Edited by A. Balows, H. G. Trüper, M. Dworkin, W. Harder \& K.-H. Schleifer. New York: Springer. 